\title{
ASPECTOS DO COMPORTAMENTO ALIMENTAR DO MORCEGOS HEMATÓFAGO, DESMODUS ROTUNDUS 1
}

\author{
Ivan Sazima \\ Departamento de Zoologia, \\ Universidade Estadual de Campinas, \\ 13100 . Campinas, São Paulo
}

\author{
Departamento de Zoologia, Universidade \\ Estadual de Campinas, 13100 Campinas, São Paulo
}

\begin{abstract}
RESUMO
O comportamento alimentar do morcego hematófago, Desmodus rotundus, junto ao gado bovino e equino, foi observado em condiçōes naturais, na região de Campinas, São Paulo. Grande parte dos resultados concorda com as informações disponíveis sobre os hábitos deste morcego em outras localidades neotropicais. $O$ início da sua atividade alimentar esteve relacionado com a ausência de luar. Esta espécie utilizou abrigos noturnos temporários, próximos ao gado, antes e depois das investidas alimentares. Nestes abrigos, foi observado o comportamento de manutenção da distância individual entre os morcegos (emissão de guinchos, empurrões e investidas). $\mathrm{O}$ ataque ao gado confinado em estábulos foi precedido pelo pouso, nas paredes internas, por um certo período ("investigação do local"). Três posturas básicas, adotadas pelos morcegos, permitem apoiar-se, durante a alimentação, no chão ou na vítima. No chão, apenas a postura quadrúpede foi observada; na vítima, as posturas agachada e pendurada foram adotadas. Aparentemente, a "preferência" dos morcegos por um certo local no corpo das vítimas poderia ser atribuída, em parte, à "acessibilidade" do local, qualidade que depende tanto das possíveis posturas adotadas pelos morcegos, como do comportamento da vítima. As interaçōes observadas entre os morcegos, nos locais de alimentação, incluíram indivíduos alimentando-se juntos, outros alimentando-se sucessivamente numa mesma mordedura e, ainda, uma disputa entre dois morcegos numa mesma mordedura. Um possível "grito de alarme" foi observado numa ocasião. $O$ número de mordeduras observadas por noite não correspondeu ao número de morcegos que se alimentaram no gado e, raramente, a mesma mordedura foi refeita na noite seguinte.
\end{abstract}

(1) Recebido para publicação em 15 de dezembro de 1975. 


\section{ABSTRACT}

Foraging behavior on cattle and horses was observed for the common vampire bat, Desmodus rotundus, under field conditions near Campinas, São Paulo, southeastern Brazil. Most of the results agree with the information available for vampires from other neotropical sites. The start of foraging activities of the bats was related to absence of moonlight. Temporary night roosts near the livestock were used both before and after feeding. "Spacing behavior" (vocalization, jostling, and drives) was observed among the bats at these roosts. The attacking behavior on cattle confined to barns was preceded by a period of roosting on the internal walls ("investigation of the place"). Three basic postures adopted by the bats during fedding allow biting from the ground or the victim: on the ground, only a quadrupedal posture was used; on the animal, crouching and pendent postures as well. Much of the "preference" of the bats of certain body sites seems attributable to the "accessibility" of these sites, depending on the possible bat postures and on the victim's behavior. Interactions observed between the vampires included individuals feeding side by side, others feeding consecutively from a wound, and a dispute at one wound. An "alarm call" was observed once. The number of wounds made nightly was not equal to the number of bats which fed on the livestock, and a given wound was seldom reopened in a subsequent night.

\section{INTRODUÇÃO}

Os morcegos hematofagos (Phyllostomidae, Desmodinae) representam um pequeno grupo de mamíferos com hábitos "semi-parasitários", alimentando-se exclusivamente do sangue de vertebrados homotérmicos. Diversas particularidades da morfologia e da biologia destes quirópteros estão diretamente relacionadas ao seu regime sanguívoro (Walker, 1975). Os três gêneros conhecidos, Desmodus, Diaemus e Diphylla, são monotípicos e restritos aos Neotrópicos (Villa-R., 1966); Desmodus rotundus ocorre do México à Argentina, sendo, atualmente, reconhecidas 2 subespécies: a forma nominal, na América do Sul e $D$. rotundus murinus, no México e América Central, embora Husson (1962) questione a sua validade.

Os hábitos de Desmodus rotundus mereceram numerosos estudos, devido tanto ao seu interesse biológico, quanto à sua importância sanitária (veja extensa bibliografia em Ditmars \& Greenhall, 1935; Constantine, 1970; Greenhal, 1972 e Turner, 1975). O gado bovino e equino figura entre os animais mais atacados por Desmodus, podendo ser, às vezes, a sua única fonte alimentar. Dalquest (1955) e Crespo et al. (1961) sugeriram que a presença de morcegos hematófagos em certos locais seria pouco provável na ausência de gado. Desmodus pode constituir colônias com dezenas a centenas de indivíduos e mantém, habitualmente, relaçōes sociais do tipo limpeza mútua (Greenhall, 1965a), podendo haver hierarquia nos locais de alimentação (Schmidt \& Greenhal, 1972). Os hábitos alimentares e sociais destes quirópteros e a sua relação com

o gado contribuem para a propagação da raiva paralítica e isto explica, em parte, o grande interesse no estudo destes animais nos últimos 40 anos (Constantine, 1970).

Referências sobre hábitos sanguívoros em Desmodus datam dos meados do século XIX (Husson, 1962), embora até recentemente, diversos aspectos da sua alimentação tenham permanecido práticamente desconhecidos. Ditmars \& Greenhall (1935) fizeram as primeiras observaçð̃es sistemáticas sobre o comportamente alimentar de 
D. rotundus, do Panamá e Trinidad. Estudos sobre aspectos do comportamento alimentar desta espécie foram feitos principalmente por Mann (1951) no Chile; Crespo et al. (1961) na Argentina; Goodwin \& Greenhall (1961) em Trinidad; Dalquest (1955), Villa-R. (1966), Wimsatt (1969), Greenhall et al. (1971) e Greenhall (1972) no México e Young (1971) e Turner (1975) em Costa Rica. Destes, Greenhall et al. (1971), Young (1971) e Turner (1975) apresentaram a visão mais compreensiva das atividades alimenatres de Desmodus em condições naturais; os demais trabalhos dão maior ênfase a outros aspectos da sua biologia, embora também abordem a alimentação. Pouco foi publicado sobre os hábitos alimentares deste morcego, no Brasil, à parte de observações de caráter geral, como as de Hensel (1869), Torres (1935) e Ruschi (1951a). Mais recentemente, Carvalho (1969) examinou aspectos da biologia dos três gêneros hematófagos, incluindo observações sobre alimentação e Villa-R. et al. (1969) estudaram uma amostra de morcegos brasileiros, para determinação do regime alimentar.

Para conhecer alguns dos problemas envolvidos no estudo dos hábitos de Desmodus $r$. rotundus, fiz um breve estudo do comportamento desta espécie, em condições naturais, na região de Campinas, estado de São Paulo. Este estudo sobre comportamento alimentar foi feito, primáriamente, devido ao meu interesse pelo enfoque etológico como método de trabalho em biologia de morcegos. Por outro lado, o conhecimento da etologia de Desmodus pode ser de uso imediato nas tentativas de controle tanto das populações deste morcego (Schmidt et al, 1970; Linhart et al., 1972; Turner, 1975), como da propagação da raiva dos herbivoros (Schmidt \& Greenhall, 1972).

\section{PROCEDIMENTO}

As observações foram feitas na região de Souzas, Campinas, estado de São Paulo (aprox. $22^{\circ} 50^{\prime} \mathrm{S}, 46^{\circ} 58^{\prime} \mathrm{W}$ ), com altitude variável em torno de $680 \mathrm{~m}$. Na região, o período mais quente e chuvoso está situado entre novembro e fevereiro e o período mais frio e seco, entre maio e agosto. $O$ volume anual médio de chuvas é de $1366,8 \mathrm{~mm}$, sendo os meses mais chuvosos dezembro e janeiro (total $469,8 \mathrm{~mm}$ ) e os mais secos, julho e agosto $(60,0 \mathrm{~mm})$. A temperatura média anual é de $22,4^{\circ} \mathrm{C}$ (média das mínimas $15,5^{\circ} \mathrm{C}$ e média das máximas $27,3^{\circ} \mathrm{C}$ ). A umidade relativa média anual é de $72,5 \%$ (dados climatológicos fornecidos pela Seção de Climatologia Agrícola, Inst. Agronômico de Campinas, com médias de 35 anos, de 1929 a 1974). A topografia gerâl da região varia de suave a fortemente ondulada e a cobertura vegetal consiste principalmente de pastagens e culturas, havendo alguns remanescentes de mata sub-tropical latifoliada. $\mathrm{Na}$ região há diversas fazendas de criação de gado bovino, principalmente para abate.

Na Fazenda Atalaia, onde foi feita a maioria das observações, o gado permanecia no pasto, durante a noite, com exceção de um pequeno grupo de 6 a 10 reses, confinado a um curral; nas imediações havia várias construções, usadas com estábulo, esterqueira e abrigo para ferramentas agrícolas. Uma colônia de Desmodus rotundus, com aproximadamente 300 indivíduos, abrigava-se no porão de uma tulha, distante cerca de $100 \mathrm{~m}$ do curral. 
As observações noturnas foram feitas em 19 sessões com duração variável entre 3 e $4 \mathrm{~h}$, totalizando $71 \mathrm{~h}$. As sessões foram feitas nas seguintes ocasiões: 1974 dezembro (5 noites); 1975 janeiro (3), março (2), julho (3), agosto (2), setembro (3) e outubro (1). Procurei abranger a maior diversidade possível de condições, desde época chuvosa até seca, incluindo fases de lua e horários diversos.

A descrição do comportamento dos morcegos durante a alimentação foi feita a partir de observação visual direta, combinada com análise de 38 fotografias. As tomadas fotográficas visavam atenuar as dificuldades na observação desta espécie, fortemente lucífuga (Dalquest, 1955; Greenhall et al., 1971). As observaçōes noturnas foram feitas à luz de lanternas comuns, com o vidro coberto por plástico vermelho, (ou filtro vermelho do tipo empregado em fotografias), e carregadas com pilhas fracas. Greenhall et al. (1971) comentaram sobre as limitações deste método, uma vez que Desmodus não é totalmente insensível a este tipo de iluminação (as excelentes observações dos autores citados foram feitas com o auxílio de aparelhos para visão noturna, "night vision scopes").

0 grupo de gado usado durante as observações noturnas era composto por 6 bovinos e 4 equinos (dezembro a março) e 10 bovinos e 3 equinos (julho e agosto). As observações de setembro e outubro foram feitas sobre um número variável de cabeças. Os bovinos usados eram mestiços de holandês com zebu, com exceção de um indivíduo, mestiço de nelore com tabapuã. As suas cores eram cinza claro, branco malhado de castanho, branco malhado de preto, preto. Os equinos eram mestiços (raças não precisadas) e as suas cores eram pardo claro, branco malhado de castanho, preto.

Além das observações noturnas sobre o comportamento dos morcegos, foram feitos exames minuciosos num grupo experimental de reses, durante 5 dias consecutivos, para localização e contagem das mordeduras sofridas durante a noite anterior. Os exames diurnos eram feitos nas primeiras horas da manhã, visando verificar as preferências dos hematófagos por certas regiōes do corpo da vítima e a frequêencia de mordeduras por rês, por noite. A série de exames foi feita no período de 10 a 14 de janeiro de 1975. Durante esse período não eram feitas observações noturnas, para afastar a possibilidade de alterar a freqüência de visitas dos morcegos ao gado devido à presença de observadores. Além desta série, algumas verificaçōes esporádicas foram feitas em julho e agosto.

\section{RESULTADOS}

A) Período de atividade alimentar

As observações sobre os horários e períodos de atividade dos morcegos estão resumidas na Tabela 1.

B) Locais de pouso noturno

Os morcego foram observados usando locais de pouso temporário, durante o seu período de atividade alimentar. Estes locais podiam ser o próprio abrigo do gado 
TABELA 1

Horário e períodos de atividade alimentar de Desmodus rotundus e sua relação como o luar.

\begin{tabular}{|c|c|c|c|c|c|c|c|}
\hline \multirow{2}{*}{ Data } & \multicolumn{2}{|c|}{$\begin{array}{l}\text { Período de } \\
\text { observações }\end{array}$} & \multicolumn{3}{|c|}{ Lua } & \multicolumn{2}{|c|}{$\begin{array}{l}\text { Atividade alimentar } \\
\text { observada no período }\end{array}$} \\
\hline & $\begin{array}{l}\text { Início } \\
\text { (Hora a }\end{array}$ & $\begin{array}{l}\text { Término } \\
\text { oximada) }\end{array}$ & Fase & $\begin{array}{l}\text { Aparição } \\
\text { (Hora ap }\end{array}$ & $\begin{array}{l}\text { Desaparição } \\
\text { roximada) }\end{array}$ & $\begin{array}{l}\text { Início } \\
\text { (Hora ap }\end{array}$ & $\begin{array}{l}\text { Término } \\
\text { oximada) }\end{array}$ \\
\hline \multicolumn{8}{|l|}{1974} \\
\hline 28 dez. & 18,15 & $22,00^{\prime}$ & Crescente & Nublado & $?$ & $18,50^{\prime}$ & $?$ \\
\hline \multicolumn{8}{|l|}{1975} \\
\hline 04 jan & $18,30^{\prime}$ & $22,00^{\prime}$ & Minguante & $20,30^{\prime}$ & $?$ & $19,15^{\prime}$ & $20,25^{\prime}$ \\
\hline 14 jan & $19,00^{\prime}$ & $22,00^{\prime}$ & Nova & - & - & $19,30^{\prime}$ & $?$ \\
\hline 24 mar. & $01,30^{\prime}$ & $05,30^{\prime}$ & Crescente & $?$ & $02,00^{\prime}$ & $02,30^{\prime}$ & $05,00^{\prime}$ \\
\hline 01 jul. & 18,30 & $21,45^{\prime}$ & Minguante & Nublado & $?$ & $19,10^{\prime}$ & $?$ \\
\hline 25 jul. & $19,00^{\prime}$ & $22,20^{\prime}$ & Cheia & $20,40^{\prime}$ & $?$ & $19,00^{\prime}$ & $20,45^{\prime}$ \\
\hline 15 ago. & $19,00^{\prime}$ & $22,00^{\prime}$ & Crescente & $19,10^{\prime}$ & $?$ & \multicolumn{2}{|c|}{ Nenhuma } \\
\hline 11 set. & $20,00^{\prime}$ & $23,00^{\prime}$ & Minguante & $>18,00$ & $?$ & \multicolumn{2}{|c|}{ Nenhuma } \\
\hline
\end{tabular}

Obs.: Estes 8 exemplos foram escolhidos como representativos das 19 observações realizadas.

(estábulo, esterqueira) ou as construções usadas para guardar ferramentas, localizadas junto ao curral. Nos locais de pouso noturno podiam formar-se ajuntamentos de até 20 indivíduos (como em 24 de março, às 2,00 h); todavia, dois a cinco era o número habitualmente observado. Nas traves e paredes onde pousavam, os morcegos ficavam agrupados ou então distanciados entre si por até cerca de $2 \mathrm{~m}$.

Pousados, adotavam a "postura de contacto" característica (Fig. 1). Quando perturbados, deslocavam-se com agilidade pelas paredes verticais, locomovendo-se lateralmente ou recuando, agarrados com as unhas às asperezas do substrato. Os seus deslocamentos na parede dos abrigos faziam lembrar a locomoção de certas aranhas ou alguns caranguejos.

Nos abrigos noturnos, observei algumas ações recíprocas entre os morcegos, como emissão de guinchos curtos e pipilos, empurrões laterais com o corpo e, eventualmente, investidas por parte de indivíduos que já estavam no pouso, contra os que chegavam. 


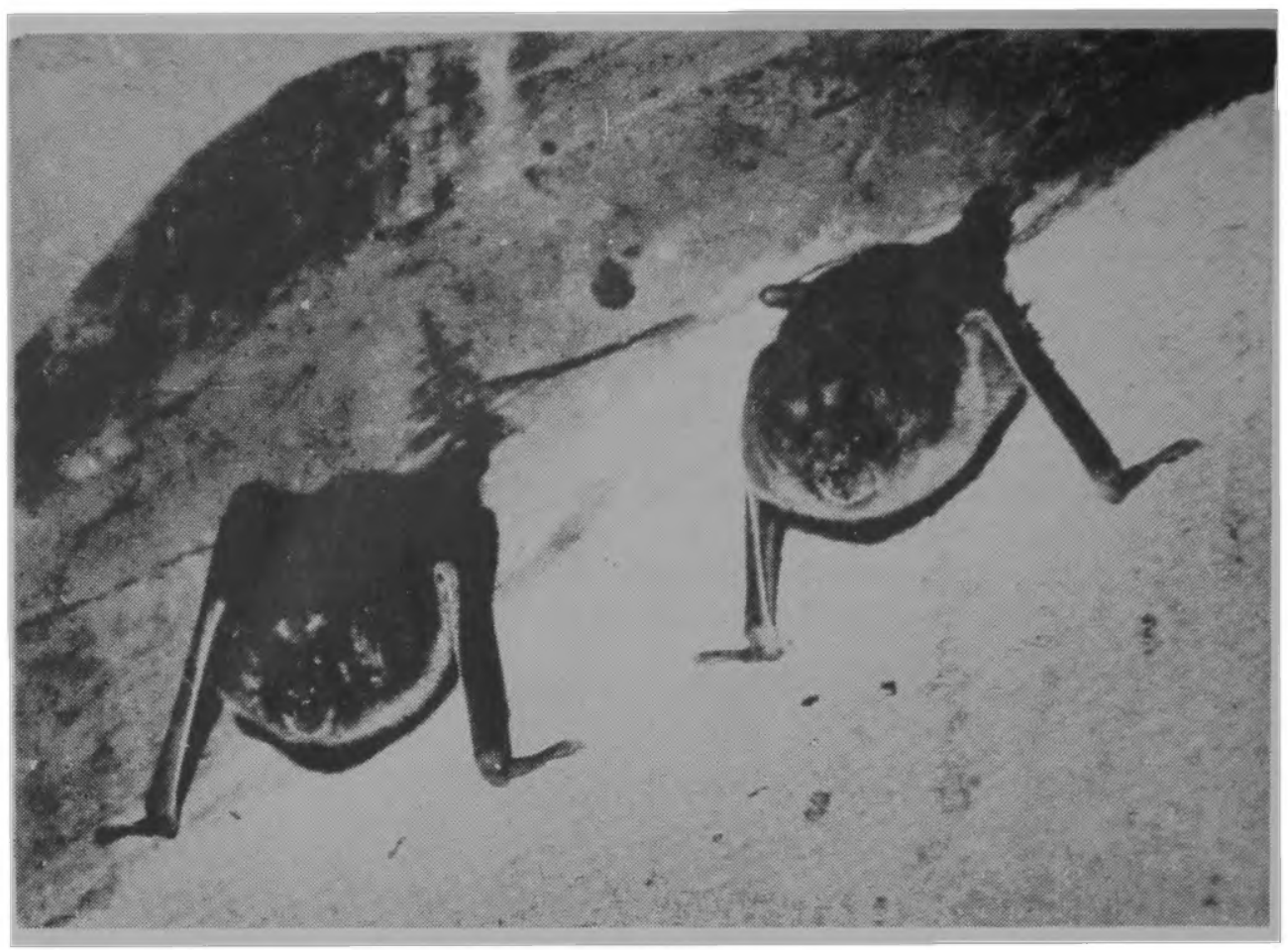

Figura 1 - Dois indivíduos do morcego hematófago, Desmodus rotundus, pousados na parede do abrigo temporário noturno. Note a característica postura de contacto adotada na ocasião.

Durante as investidas, o animal permanecia agarrado com os pés e, apoiado nos polegares, movimentava a cabeça e a parte anterior do corpo em direção ao recém-chegado, emitindo guinchos curtos. Em algumas ocasiões, o indivíduo que já estava no pouso podia realizar curtos deslocamentos para a frente, em direção ao recém-chegado, dando-lhe "empurrões" com o focinho. O recém-chegado podia abandonar o pouso ou então, acomodar-se ao lado dos demais morcegos.

Os abrigos podiam ser utilizados antes das investidas ao gado e também quando os morcegos interrompiam a alimentação. Nessas ocasiões, defecavam nos locais de pouso, deixando manchas escuras características nas paredes ou no chão do abrigo. As manchas fecais parecem gotas de alcatrão, escorridas pelas paredes ou formando pequenos acúmulos no chão. Não chegam a formar, porém, grande poças como os acúmulos comumente observados no chão da moradia diurna das espécies hematófagas.

A presença de manchas fecais levou à descoberta de um abrigo noturno situado num pasto, distante cerca de $2 \mathrm{~km}$ da colônia de morcegos da Fazenda Atalaia. $\mathrm{O}$ abrigo ficava às margens de um pequeno riacho, em barranco erodido, situado no interior de um bambuzal (o barranco formava uma espécie de cobertura, sustentada pelas raízes dos bambus). A presença de hematófagos durante a noite foi registrada de maneira indireta, pela contagem de manchas fecais no chão do abrigo, que era coberto por papel 
diáriamente renovado. Cada manhã, havia manchas fecais em cerca de 15 pontos distintos no chão, sugerindo a presença de número aproximadamente igual de morcegos usando o abrigo, no período de 10 a 14 de janeiro. Neste mesmo período, um pequeno grupo de bovinos usou o bambuzal, à noite.

\section{C) Comportamento alimentar}

\section{Aproximação dos morcegos ao gado}

A aproximação de Desmodus ao gado confinado em locais cobertos (estábulo, esterqueira) era precedido pelo pouso nas paredes internas da construção. Permaneciam pousados por um período variável de 1 a $20 \mathrm{~min}$, voando a seguir diretamente para a vítima, podendo pousar no seu corpo ou no chão. Para a aproximação ao gado confinado em locais descobertos (curral, piquete) os morcegos podiam fazer ajuntamentos de dois a cinco indivíduos, nos abrigos próximos e, passado algum tempo, de lá voar até o gado. O pouso podia ser feito no chão ou no corpo da vítima (no caso de reses em pé, o pouso no corpo da vítima era mais comum). Somente a aproximação ao gado bovino foi observada; nos equinos, devido à maior distância de observação, os morcegos só eram percebidos quando já pousados, comumente agarrados à crina.

$\mathrm{O}$ pouso no chão podia ser feito numa distância de até $1 \mathrm{~m}$ da vítima, deslocando-se o morcego em seguida, adotando a marcha quadrúpede característica desta espécie. Após chegar ao corpo da vítima, o morcego ficava apoiado no chão, para se alimentar. Não foi observado nenhum indivíduo escalando o corpo da vítima, a partir do chão, para se alimentar.

Poucas vezes observei alguma reação do gado à presença dos morcegos, mesmo quando o seu pouso era feito diretamente no corpo da vítima. A reação observada, nos bovinos, consistia num movimento da cabeça da rês em direção ao animal, que nestas ocasiōes podia voar, retornando em seguida ao mesmo local. Nestas circunstâncias, o morcego mostrava-se muito alerta e ágil. O levantar vôo podia ser precedido por um pulo para trás ou uma curta corrida para o lado. Os morcegos podiam permanecer no dorso das suas vítimas mesmo durante ocasiōes de grande movimentação entre o gado, com marradas e perseguiçōes. Numa ocasião, um dos morcegos abandonou o corpo da vítima quando esta foi coberta, durante uma tentativa de cópula. Um muar, observado esporádicamente em 1 de julho, deitava-se frequentemente, esfregando o dorso e os flancos contra o chão (em duas oportunidades, este comportamento foi observado em seguida ao pouso de um morcego na espádua do animal).

Tanto na aproximação, como no pouso e levantar vôo, o modo de voar de Desmodus era direto e vigoroso, parecendo pouco manobrável.

\section{Comportamento durante a alimentação.}

Não foram observados o comportamento de escolha do local para a mordida, o ato de morder a vítima e a duração de cada refeição. 
As posturas adotadas pelos morcegos, durante a alimentação, variavam principalmente com o substrato usado como apoio (chão ou corpo da vítima) e o local escolhido para a mordida. Assim, durante a tomada de sangue, podia ser assumida uma destas tres posturas básicas: "quadrúpede", "agachada" ou "pendurada"

A postura quadrúpede era adotada em superfícies horizontais ou ligeiramente inclinadas. Nesta postura, o animal permanecia com as asas recolhidas e apoiava-se na face palmar dos polegares e na região plantar, com o corpo elevado do substrato. A posição do seu corpo podia variar de horizontal, até práticamente vertical (Fig. 3), de acordo com a situação do local mordido. Quando pousado no chảo, o morcego mantinha a cabeça erguida e durante a tomada de sangue, conservava o focinho dirigido para a frente e para cima, estirando o pescoço. Assumia essa postura para se alimentar na região da axila (Fig. 2), joelho, ventre e base da cauda da vítima deitada. No caso da vítima estar em pé, o morcego adotava a postura quadrúpede ao se alimentar na região do casco.

A postura quadrúpede também foi observada em morcegos pousados no corpo da vítima. Neste caso, mantinham o corpo em posição aproximadamente horizontal e a cabeça abaixada. Durante as interrupções da tomada de sangue, podiam agachar-se um pouco, mas em nenhuma ocasião o seu ventre foi observado em contacto com o substrato. No corpo da vítima, a postura quadrúpede era adotada na região dorsal (espádua, lombo, anca).

A postura agachada era também adotada em superfícies horizontais ou ligeiramente inclinadas, mas diferia da quadrúpede em uma característica básica: o ventre do morcego permanecia em contacto com o substrato (Fig. 4). Essa postura foi observada somente em indivíduos pousados nas suas vítimas, alimentando-se na região do lombo.

A postura pendurada era adotada em superfícies fortemente inclinadas ou verticais. $\mathrm{O}$ morcego permanecia com as asas recolhidas, agarrado ao substrato com o auxilio das unhas dos pés e polegares e apoiado na face plantar e palmar dos mesmos, sempre estando a região anterior do seu corpo voltada para baixo. $\mathrm{O}$ ventre podia tocar o substrato. O pescoço curvava-se lateralmente, possibilitando ao animal tomar sangue, estando com a cabeça em posição quase horizontal (Fig. 5). Nos bovinos, os morcegos assumiam essa postura ao se alimentarem na região da espádua (Fig. 6) e do pescoço; nos equinos, permaneciam pendurados na crina e mordiam a vítima na região da espádua, pescoço, queixo e próximo dos olhos.

Em qualquer das posturas, o morcego mantinha o corpo práticamente imóvel durante a tomada de sangue e o exame de duas fotografias mostra a sua lingua em contacto com o local mordido. Esse contacto podia ser interrompido quando o local era diretamente iluminado por alguns instantes, ocasião em que o animal se encolhia ligeiramente, mas não mudava de posição. Passado algum tempo, assumia a postura original, refazendo o contacto com a mordedura ou então voava, afastando-se do local. Alçava vôo após uma curta caminhada ou diretamente do local onde se encontrava, indiferentemente se era no chão ou na vítima. (Um indivíduo, que se encontrava no chão, foi observado escalando rápidamente o corpo de um bovino deitado, até alcançar o lombo, de onde alçou vôo em seguida). Quando a vítima se movia, durante a tomada de sangue, o morcego interrompia a refeição e ficava alerta aos movimentos ao seu redor. Se havia 


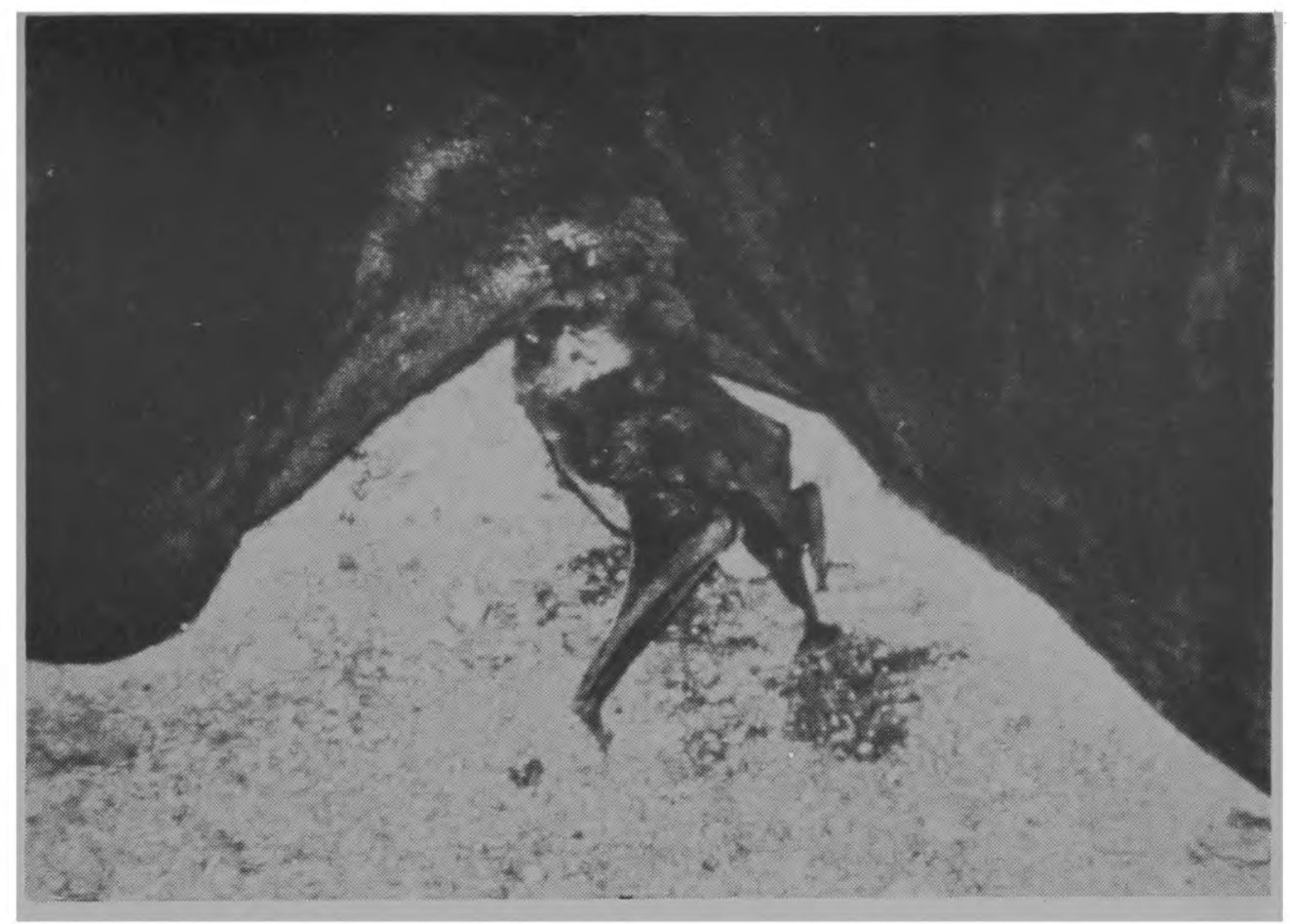

Figura 2 - Desmodus rotundus alimentando-se na axila de bovino deitado. Note a postura quadrúpede adotada pelo morcego e as manchas de urina próximas ao seu ventre e seu pé esquerdo.

a ameaça de ser pisado ou golpeado, afastava-se rapidamente do local mordido e nestas circunstâncias, o seu deslocamento podia ser aos pulos, correndo ou voando, com grande agilidade nas tres alternativas. Por ocasião da tomada de sangue, os morcegos habitualmente urinavam, formando manchas bem visíveis (Fig. 2).

A mordedura produzida por Desmodus, para se alimentar, possui formato aproximadamente circular ou elíptico, variando de 3 a $6 \mathrm{~mm}$ no seu maior comprimento. A ferida consiste numa depressão côncava, relativamente rasa (ca. $3 \mathrm{~mm}$ ) e com bordos bastante regulares. $O$ local da mordedura geralmente sangrava bem, formando um filete de sangue que escorria pelo flanco da vítima (Fig. 6) ou, ainda, empoçava no chão, especialmente quando a mordedura era feita no focinho, pé, cauda ou axila. Dois bovinos foram observados lambendo a mordedura, feita em seu flanco, após a saída do morcego. Com este procedimento o sangue escorrido era removido, deixando a ferida limpa. 

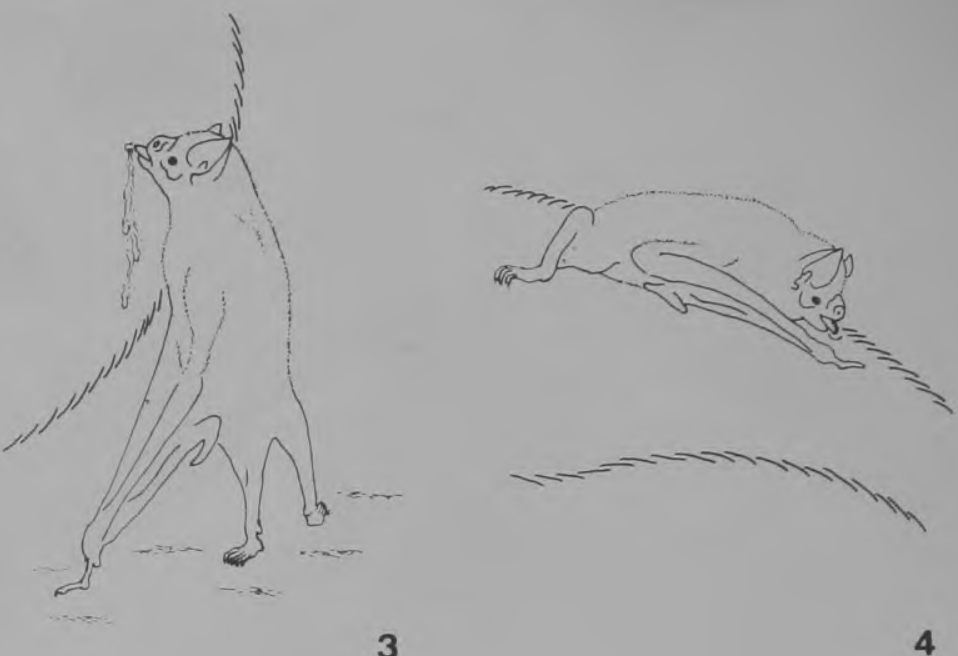

3

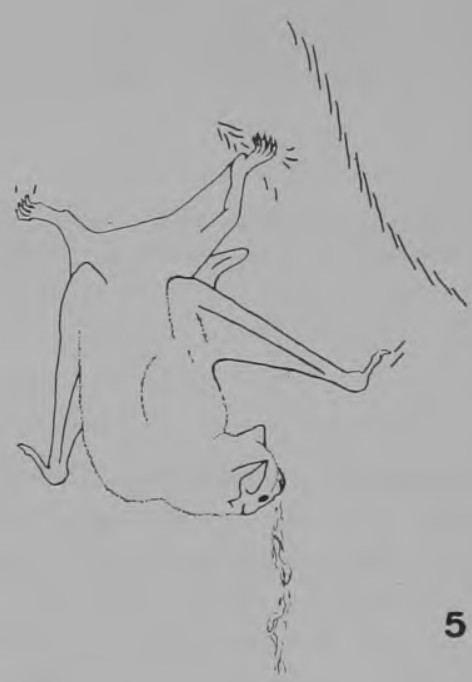

Figura 3 a 5 - Três posturas básicas adotadas por Desmodus rotundus durante a tomada de sangue em gado. Figura 3 - Postura quadrúpede, apoiado no solo e mordendo o traseiro de bovino deitado. Note a posição quase vertical do morcego e o uso do polegar. Figura 4 - Postura agachada, com o ventre apoiado no lombo de bovino. Figura 5 - Postura pendurada, em espádua de bovino. 


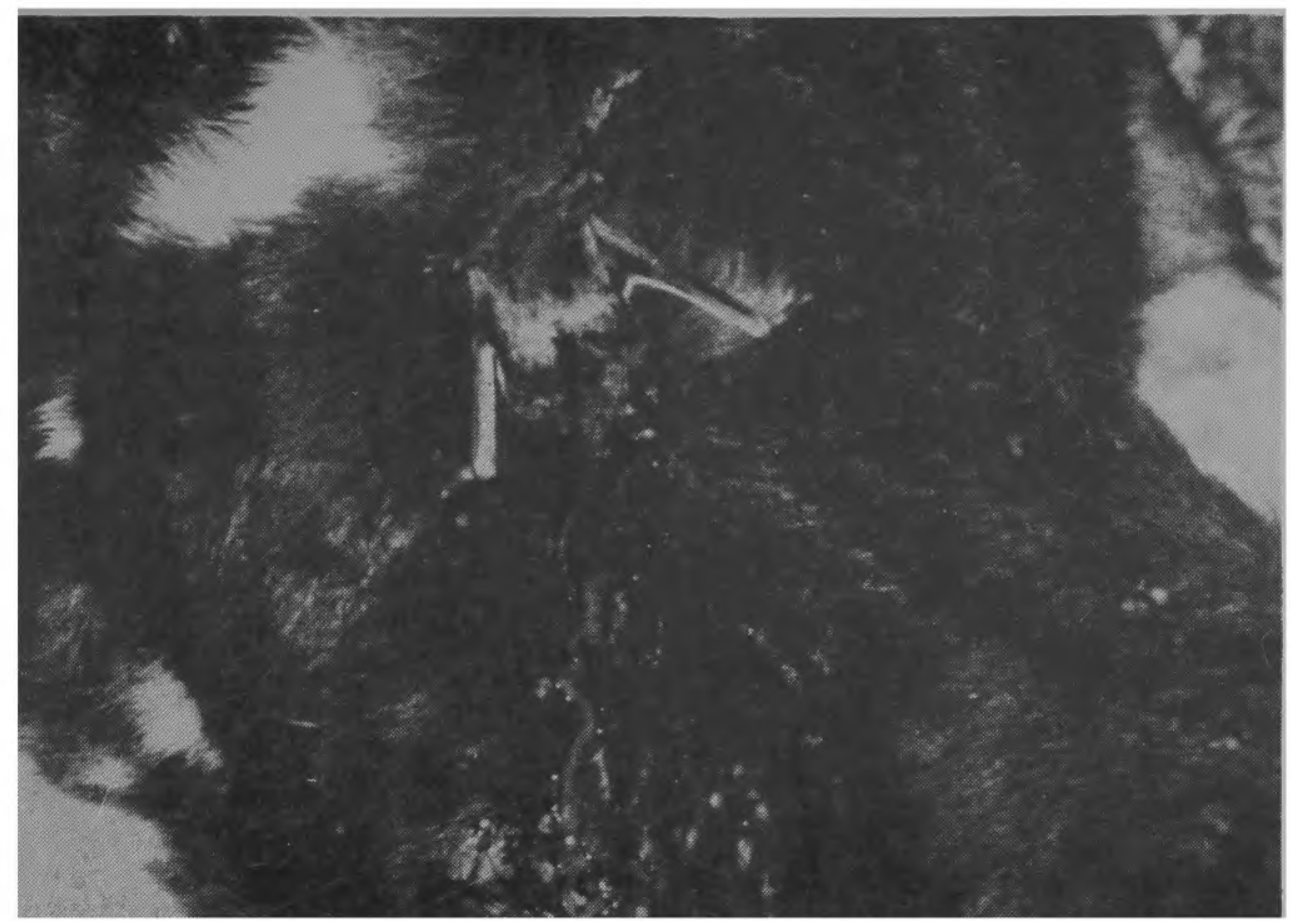

Figura 6 - Postura pendurada, adotada por Desmodus rotundus ao se alimentar em espádua de bovino. Note o filete de sangue escorrido da mordedura.

3. Interações dos morcegos durante a alimentação.

Um mesmo bovino foi observado sendo atacado por tres morcegos simultâneamente (28 de dezembro, ca. 20,30 h). Um dos indivíduos estava se alimentando na axila da vítima, que se encontrava deitada, e os dois restantes estavam no lombo. Estes dois indivíduos estavam pousados muito próximos um do outro e, aparentemente, tomando sangue do mesmo local (não consegui verificar se o sangue fluía de uma única ferida ou de mais feridas, muito próximas. A presença simultânea de dois morcegos em partes diferentes de uma mesma vítima era comum e as partes atacadas podiam ser tão diversas como lombo e axila, flanco e focinho, pata e pescoço. Observei, em duas ocasiōes, a sucessão de dois indivíduos diferentes, numa única ferida (os indivíduos foram diferenciados por marcas naturais, como cor da pelagem e região desprovida de pelos na cabeça, num deles). Uma das mordeduras, feita na axila de um bovino deitado, foi visitada por dois morcegos, sucessivamente, no decorrer de uma hora (24 de março, das 3,20 às $4,20 \mathrm{~h}$ ). A segunda observação, feita em 1 de julho (ca. $20,00 \mathrm{~h}$ ), envolvia uma ferida na espádua de um bovino, também deitado. Esta mordedura foi visitada 


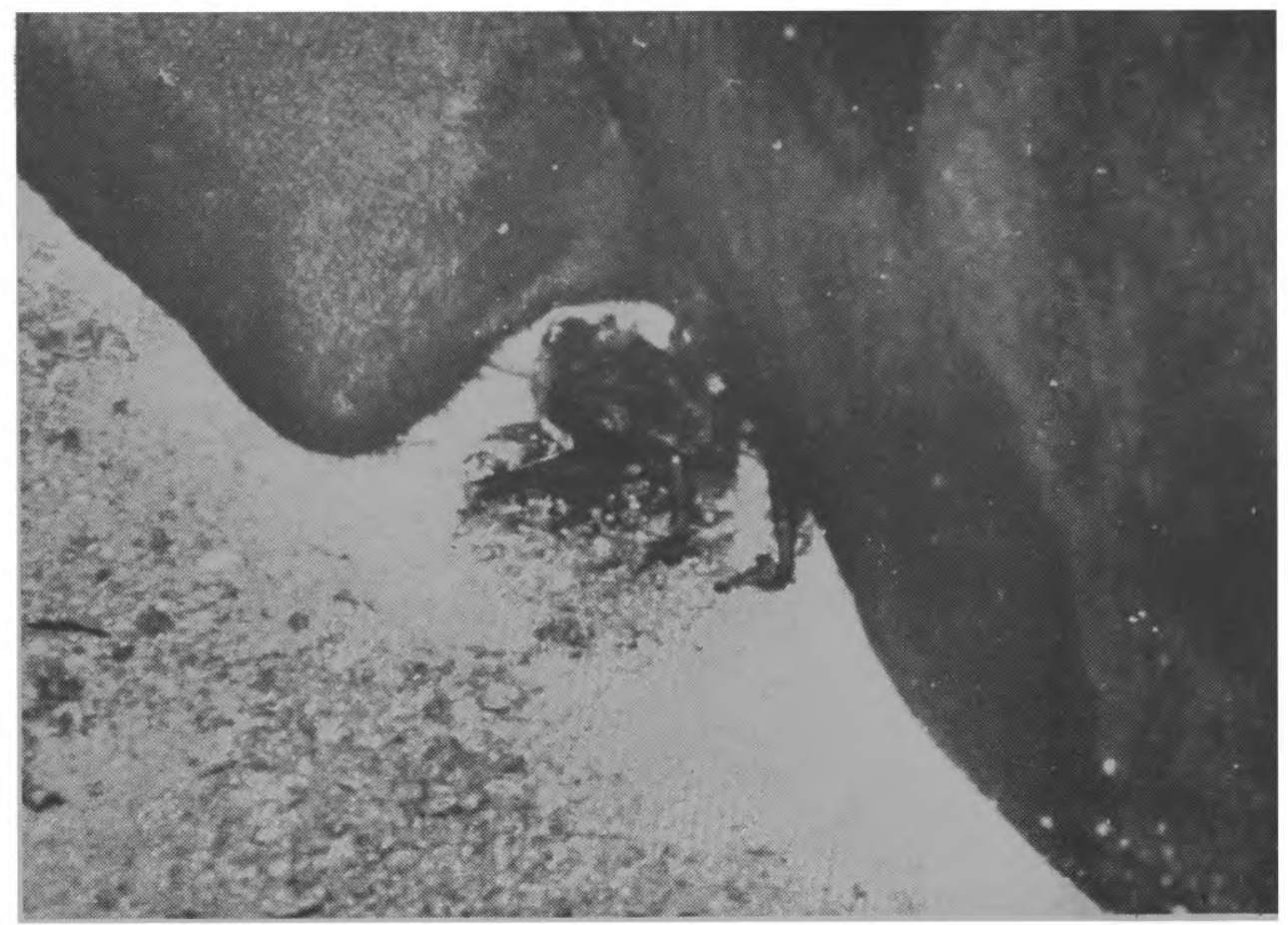

Figura 7 - Comportamento agonístico em Desmodus rotundus, junto a mordedura em axila de bovino deitado. O morcego à direita está parcialmente oculto pelo flanco da rês (veja o texto para maiores explicações).

por dois indivíduos no espaço de $20 \mathrm{~min}$, aproximadamente. Em ambos os casos, somente percebi a presença do segundo morcego, na ferida, por ocasião do exame dos bovinos por iluminação direta, não tendo observado o momento em que o primeiro abandonou a vítima.

Uma "disputa" entre dois morcegos, no local da alimentação, foi observada numa ocasião ( 24 de março, ca. $4,40 \mathrm{~h}$ ). Ao ser iluminado diretamente um dos bovinos deitados, o morcego que estava se alimentando na axila, refugiou-se no espaço formado entre o chão e o flanco da vítima, permanecendo aí por alguns instantes. Logo após apagada a luz, foi percebida a chegada de um outro indivíduo que pousou próximo da axila que sangrava. No mesmo momento foram ouvidos guinchos e batidas de asas. A fotografia tomada na ocasião (Fig. 7), mostra o primeiro indivíduo, parcialmente oculto pelo flanco da vítima, empurrando, com o antebraço esquerdo, o flanco direito do recém-chegado, que está agachado contra o substrato. 
Na mesma data (ca. 4,00 h) observei um morcego alimentando-se na pata traseira de um bovino, que se encontrava deitado. Com o objetivo de verificar a "distância de fuga" deste morcego, aproximei-me devagar e quando estava a menos de $3 \mathrm{~m}$, o animal subitamente alçou vôo, emitindo, concomitantemente, uma série de sons agudos e repetitivos. No mesmo instante, levantaram vôo mais cinco ou seis outros morcegos, inclusive dois que estavam do lado oposto, atrás dos corpos das suas vítimas e, aparentemente, impedidos de perceber visualmente a minha aproximação.

\section{D) Localização e número de mordeduras no gado}

A localização e o número das mordeduras sofridas pelo grupo experimental de gado, durante 5 noites consecutivas, são mostrados na Tabela 2.

Nos bovinos, o número total de mordeduras observadas variou de 5 a 17 , com uma média de 2 mordeduras/rês/noite. Nos quatro equinos, o número total de mordeduras variou de 11 a 18, com uma série de 3,5 mordeduras/animal/noite.

Numa mesma noite, podia haver bovino sem mordedura observada, enquanto um outro podia apresentar até 6 mordeduras registradas. No grupo de bovinos, a rês de cor cinza (mestiça de nelore com tabapuã) foi mordida uma única vez, ao longo das 5 noites, ao passo que a rês branca malhada de preto foi mordida 18 vezes, durante o mesmo período. Nas quatro reses restantes não foi verificada diferença sensível (9, 10 e 11 mordeduras nas reses pretas e 11 na branca malhada de castanho). No grupo de equinos, o animal de cor preta foi mordido 7 vezes ao longo das 5 noites; 0 animal branco malhado de castanho foi mordido 14 vezes; os dois restantes (ambos de cor parda), 24 e 25 vezes, respectivamente.

Verifiquei que uma mesma região do corpo da vítima (espádua, queixo, lombo, axila), podia aparecer mordida em quase todas as noites. Entretanto, um determinado ponto (ou ponto muito próximo) aparentemente era mordido, no máximo, em 2 noites consecutivas e, ainda assim, não era um fato muito comum, pois apenas cerca de $10 \%$ do número total de mordeduras de uma noite era refeito na noite seguinte.

\section{DISCUSSĀO E CONCLUSŌES}

De um modo geral, o comportamento alimentar de Desmodus rotundus, observado em Campinas, parece concordar com as descrições dos hábitos desta espécie em outras regiōes (Ditmars \& Greenhall, 1935; Mann, 1951; Crespo et al., 1961; Villa-R., 1966; Greenhall et al., 1971 e Tumer, 1975). Contudo, alguns das minhas observações parecem ser inéditas, ao passo que outras foram poucas vezes registradas na literatura ou, ainda, são de natureza controvertida. Wimsatt (1969), Young (1971) e Turner (1975) frisaram a necessidade de estudar $D$. rotundus em diferentes regiōes, pois há fortes indícios que os seus hábitos possam variar considerávelmente de uma localidade para outras. 
TABELA 2

Mordeduras por morcegos hematófagos,

Desmodus rotundus, nas suas vítimas. Período de 10 a 14 de janeiro de 1975.

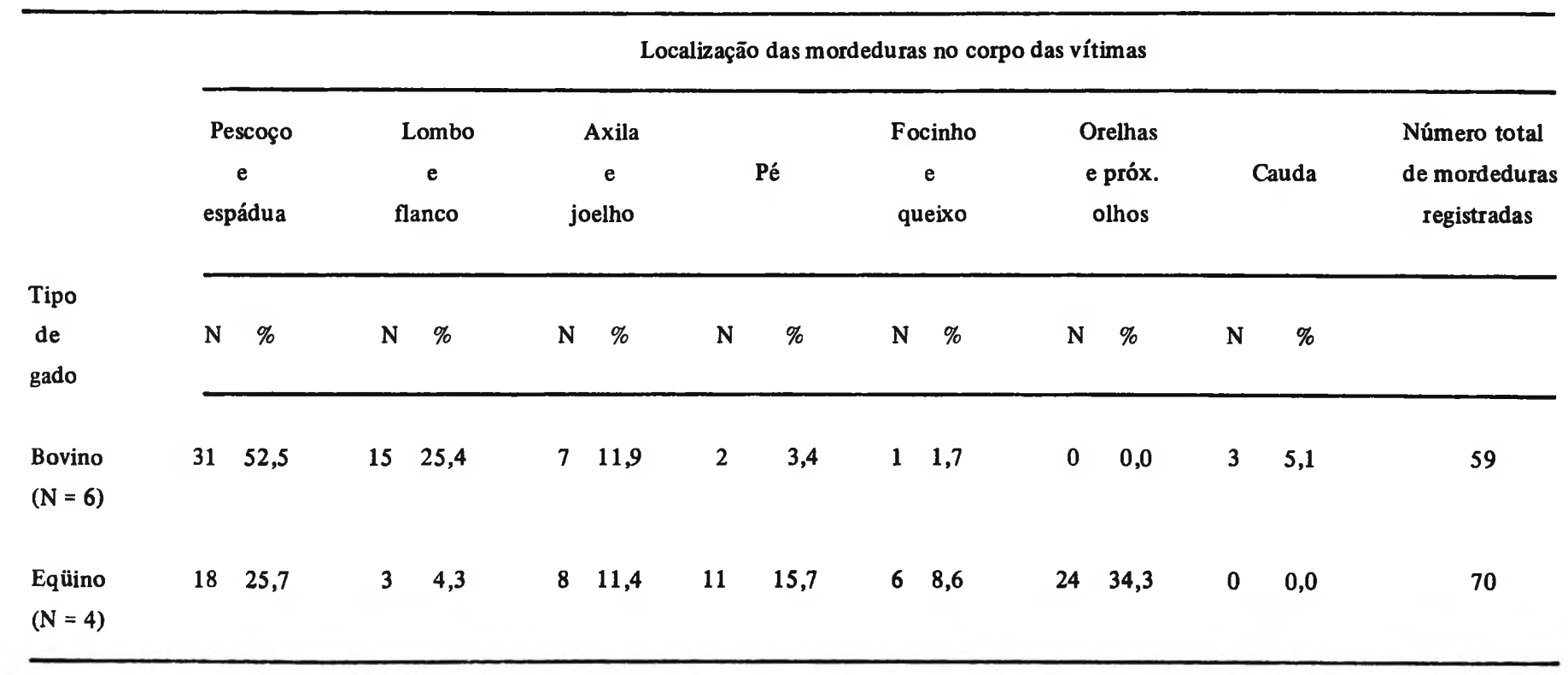




\section{A) Perfodo de atividade alimentar}

A análise da Tabela 1 sugere que o início da atividade alimentar de Desmodus está relacionado com o período mais escuro da noite. No caso de não haver luar, ou a lua estar encoberta por nuvens, a atividade desta espécie era, comumente, iniciada logo após o escurecer. Caso a lua surgisse após os morcegos terem iniciado a sua alimentação, esta era interrompida, independentemente do horário. Nas noites em que havia luar desde o escurecer, a atividade alimentar somente era iniciada após a desaparição da lua.

No México, Crespo et al. (1972) demonstraram que o período em que este morcego busca o seu alimento está estreitamente relacionado com a ausência de luar e uma comparação entre a sua tabela e a aqui apresentada, mostra semelhança. Em Costa Rica, Turner (1975) também encontrou grande correspondencia entre periodos sem luar e atividade de Demodus. Entretanto, este mesmo autor encontrou uma relação inversa entre o luar e a atividade do gado; isto é, nos períodos mais escuros, o gado estava em repouso. Como conclusão, Turner (1975) afirmiou que $D$. rotundus restringe a sua atividade alimentar a períodos sem luar e que a inatividade do gado nessa mesma ocasião reforça este padrão.

Para uma eventual tentativa de controle de morcegos hematófagos numa certa região, o conhecimento do seu perfodo de atividade alimentar tem valor na orientação dos horários de captura noturna com redes (Schmidt et al., 1970; Linhart et al., 1972). Crespo et al. (1972) afirmaram ser possível prognosticar a atividade de Desmodus, baseando-se em tabelas lunares e esse parece ser o caso.

\section{B) Locais de pouso noturno}

0 uso de pousos noturnos parece estar condicionado, principalmente, pela disponibilidade de abrigos apropriados (construções, alterações do relêvo) próximos aos locais de alimentação. Na fazenda, os abrigos mais usados eram todos relativamente fechados, e portanto escuros, e de construção não muito recente. Dalquest (1955) e Wimsatt (1969) não observaram abrigos noturnos de Desmodus no México, acreditando que este morcego se recolha à moradia diurna logo após a alimentação. Por outro lado, Goodwin \& Greenhall (1961) observaram, em Trinidad, locais de pouso noturno sendo usados após as refeições e chamaram-nos de "digesting places"; Young (1971) também suspeitou do uso de abrigos temporários, para digestão, em Costa Rica. Em Campinas, entretanto, os abrigos notumos eram usados antes das investidas ao gado e também após as refeições.

Acredito que a presença de locais apropriados para pouso notumo seja importante, proporcionando um refúgio próximo à fonte alimentar e possibilitando um período de ambientação e descanso. Ditmars \& Greenhall (1935) e Goodwin \& Greenhall (1961) citaram casos de Desmodus rotundus, em Trinidad, com tal excesso de sangue ingerido, que mal podiam voar. Um local de pouso temporário parece ser vantajoso, permitindo alijar um eventual excesso de peso, em forma de urina e fezes; a julgar pela presença de manchas fecais no chão e nas paredes dos abrigos, tal prática parece ser 
corrente. O abrigo noturno no barranco erodido indica que os locais de pouso temporário podem ser variados e mais comuns do que poderia parecer à primeira vista. A presença de manchas fecais, mesmo em pequeno número, nas paredes ou no chão de um abrigo qualquer, revela com razoável segurança a sua utilização noturna por morcegos hematófagos, fato comentado por Goodwin \& Greenhall (1961). Num programa de combate a estes animais, alguns dos abrigos assim descobertos poderiam ser parcial ou totalmente inutilizados, visando dificultar ou mesmo impedir o seu uso durante as investidas ao gado (em outros casos, tapar bem as frestas e os vãos entre o telhado e as paredes, ou iluminar o local, poderia dar resultado).

As interações dos morcegos nos abrigos noturnos (guinchos, empurrões laterais e investidas agressivas contra recém-chegados) são formas de comportamento agonístico, que parem indicar a existência de estrutura social nos locais de pouso temporário, incluindo a manutenção de "distância individual". Schmidth \& Greenhall (1972) haviam sugerido a existência de dominância social e até territorialidade em $D$. rotundus, após observarem as interações numa pequena colônia mantida em cativeiro. Penso, porém, que a organização social deste morcego, em condiçōes naturais, somente poderá ser interpretada após a individualização dos animais e observação ao longo do ano. Conhecendo o sexo e a condição de adulto ou juvenil dos indivíduos marcados, seria possível verificar que tipo de comportamento social Desmodus exibe nos abrigos noturnos. Por outro lado, os frequentes deslocamentos de indivíduos, de um abrigo para outro, verificados por Villa-R. (1966), Wimsatt (1969) e Turner (1975), dificultariam consideravelmente a tarefa.

\section{C) Comportamento alimentar}

De maneira geral, o comportamento alimentar de Desmodus rotundus é caracterizado pela versatilidade, traduzida pelos diferentes modos de aproximação, pouso, locomoção e, ainda, posturas adotadas duranite a alimentação.

\section{Aproximação dos morcegos ao gado.}

No caso de gado estabulado, parece ser importante o período de tempo em que o morcego permanece pousado nas paredes internas da construção, antes de voar até a vítima. Este período de espera pode ser comparado ao "vôo de reconhecimento" ao redor do gado situado em locais abertos, mencionado por Greenhall et al. (1971). Em ambos os casos, acredito tratar-se de um comportamento de "ambientação", no qual os morcegos examinam o local e as sua possíveis vítimas. A sugestão é reforçada pela observação de Desmodus em cativeiro (Ditmars \& Greenhall, 1935; Schmidt \& Greenhall, 1972) na qual é mencionado um certo período de espera ("investigation of the place"), antes do animal voar até a vítima. Nos estábulos, talvez devido à relativa exiguidade de espaço, o "vôo de reconhecimento" seria substituído pelo "pouso de ambientação" 
O modo de voar desta espécie de morcego, direto e vigoroso, é compatível com os seus hábitos alimentares, uma vez que, atualmente, a maior parte das suas vítimas pode ser encontrada em locais relativamente abertos. Seria interessante comparar a habilidade de vôo de Desmodus com a dos outros dois gêneros hematófagos, que se alimentam mais em aves e, supostamente, teriam o vôo mais manobrável em função do hábito de se empoleirar das suas vítimas. Desmodis voa por "corredores de vôo" (Brosset, 1964; Ávila-Pires, 1965) percorridos habitualmente durante a busca de alimento (Vaughan, 1972; Walker, 1975). Em conexão com isto, pode ser interessante mencionar o caso de um exemplar fêmea encontrado com a ponta da asa enganchada em cerca de arame farpado, na Fazenda Atalaia, em 23 de julho de 1975. A cerca, próxima ao curral onde o gado estava confinado, fora estendida no dia anterior, tendo, aparentemente, interceptado um dos possiveis corredores de vôo. Casos de quirópteros enganchados em arame farpado foram registrados nos gêneros insetívoros Lasiurus e Pipistrellus, Vespertilionidae (Gilette \& Kimbrough, 1970).

\section{Comportamento durante a alimentação.}

As tres "posturas básicas", adotadas por Desmodus rotundus durante a alimentação, permitem-lhe explorar as mais diversas situações. Essas posturas parecem-me nítidamente relacionadas com a inclinação do substrato usado como apoio, a sua natureza (chão ou corpo da vítima) e, ainda, a situação do local mordido no corpo da vítima. É muito provável que a "preferência" dos morcegos por um certo local do corpo da vítima, para se alimentarem (Tabela 2), seja influenciada pela postura, posição e exposição da vítima. Neste caso, é a "acessibilidade" de partes da vítima, para a mordedura, e a possibilidade de adoção de uma das posturas, que determinariam a "preferência" do morcego por um certo local no corpo da vítima.

As adaptações morfológicas de $D$. rotundus, como o longo polegar, provido de "almofadas de apoio" na face palmar, juntamente com os membros traseiros longos e fortes e o antebraço desenvolvido, permitem a adoção da postura quadrúpede, estando o corpo elevado do substrato mesmo em terreno irregular ou provido de vegetação baixa. Os mesmos atributos possibilitam, ainda, a adoção de uma posição praticamente vertical que, juntamente com o longo pescoço, permitem ao morcego morder a uma considerável altura a partir do chão (ca. $15 \mathrm{~cm}$ ). Acredito que, o pouso no chão, a marcha e a postura quadrúpedes, a capacidade de acompanhar a sua vítima, andando (Ditmars \& Greenhall, 1935; Greenhall, 1972) e a facilidade em atacá-la a partir do chão (interpretados como adaptações para alimentação em animais com hábitos terrestres), tenham contribuído decisivamente para facilitar a passagem de Desmodus, desde um regime silvestre, para um regime "doméstico", baseado em gado. Parece digno de registro que, mesmo para se alimentar em aves empoleiradas, esta espécie às vezes adota a postura quadrúpede, apoiada no poleiro (Villa-R., 1966). Por outro lado, o uso das unhas dos pés e polegares, para se agarrar durante a postura pendurada e a torção lateral do longo pescoço, possibilitam ao morcego alimentar-se estando pousado em regióes muito inclinadas ou mesmo verticais, dos corpos das suas vítimas. 0 mecanismo especializado da ingestão de sangue (Ditmars \& Greenhall, 1935; Mann, 1950; Glass, 1970) pro- 
vávelmente facilita a variedade de posturas e posiçð̄es que o morcego pode adotar durante a alimentação.

Os outros dois gêneros de morcegos hematófagos, Diaemus e Diphylla, possuem membros traseiros e polegar relativamente mais curtos que Desmodus, podendo esses atributos estar relacionados aos seus hábitos alimentares, baseados principalmente em aves (Goodwin \& Greenhall, 1961; Villa-R. et al., 1969; Walker, 1975). Em Diaemus e Diphylla, a unha do polegar é bem desenvolvida e recurva e a ausência de "almofada de apoio" muito pronunciada, na parte distal do polegar, torna a unha mais projetada, característica que.poderia proporcionar maior facilidade para se agarrar ao corpo da vítima (neste caso provida de penas, substrato de apreensão mais difícil que pelos ou crina). As informações disponíveis indicam que Diphylla pousa no corpo da vítima, onde assume a postura pendurada, para se alimentar (Moojen, 1939; Ruschi, 1951b; Walker, 1975). Moojen (1939) observou, ainda neste gênero, um tipo de postura que, pela sua descrição, poderia ser comparada à pendurada, mas com inversão total de posição (cabeça voltada para cima). Para Diaemus não achei dados comparáveis. Na possibilidade de estudar o comportamento alimentar de Diphylla e Diaemus em gado, seria interessante comparar as suas posturas com aquelas adotadas por Desmodus, nas mesmas circunstâncias. Penso que os dois primeiros gêneros pousam no corpo da vítima, adotando af a postura pendurada ou, ainda, a agachada.

Tanto a morfologia dos membros, como o comportamento, sugerem hábitos menos “terrestres" em Diphylla e Diaemus, uma das diferenças que poderiam diminuir uma eventual sobreposição de nichos alimentares entre os morcegos sanguívoros. Em algumas localidades, Desmodus e Diaemus apresentam, nítidamente, preferências alimentares distintas (Goodwin \& Greenhall, 1961). Em Coxim, Mato Grosso, Wilson Uieda e Atílio Storti Filho (comunicação pessoal) capturaram 4 exemplares de Desmodus rotundus em rede armada dentro de chiqueiro e $40 \mathrm{~m}$ adiante, 2 de Diaemus youngi, em rede armada defronte a uma árvore que servia de poleiro noturno para galinhas. Por outro lado, em Ubatuba, São Paulo, encontrei Desmodus rotundus alimentando-se em galinhas, juntamente com Diphylla ecaudata, em local onde não havia gado próximo. Villa-R (1966) também encontrou Desmodus alimentando-se em galinhas, no México. Ruschi (1951b) informou que Diphylla pode atacar gado bovino e equino; Carvalho (1969) encontrou diversos indivíduos deste gênero alimentando-se em suínos. Greenhall (1970) detectou sangue bovino no trato digestivo de Diaemus, em Trinidad, tendo interpretado este fato como uma provável transição gradual de aves para mamíferos, como fonte alimentar. Estas observações sugerem que os morcegos sanguívoros possuem uma certa potencialidade para explorar diversas fontes alimentares, podendo usá-las em algumas ocasiōes, indepententemente de maior ou menor adaptação a um certo tipo de vítimas. É possível que o regime alimentar deste grupo de morcegos tenha sido baseado primitivamente em animais arborícolas (aves?), característica que atualmente é visível em Diaemus e Diphylla, gêneros considerados menos especializados que Desmodus (Vaughan, 1972).

3. Interaçס̃es dos morcegos durante a alimentação

A presença simultânea de dois ou mais morcegos na mesma vítima e a "disputa" pelo local de alimentação foram interpretados por Greenhall et al. (1971) e Schmidt \& 
Greenhall (1972) como indicações de dominancia social e possível territorialidade, nos locais de alimentação, opiniâo compartilhada por Turner (1975). As observações feitas em Campinas, junto ao gado, lembram este tipo de relações sociais, conhecidas para outros mamíferos. A observação única, sobre disputa ao lado de uma mordedura, parece confirmar parcialmente as opiniбes dos autores citados, pois a postura adotada pelo indivíduo recém-chegado assemelha-se à "postura submissiva" encontrada em diversas espécies de mamíferos, durante encontros territoriais intra-específicos (Ewer, 1968). Entretanto, Schmidt \& Flierdt (1973 apud Turner, 1975) não observaram posturas submissivas nos encontros agonísticos de morcegos junto ao alimento, em cativeiro. Young (1971) encontrou uma grande variação no número de indivíduos presentes simultaneamente numa mesma vítima, de acordo com a estação seca ou chuvosa. Claramente, aqui também seria necessário o estudo de animais marcados, para se chegar a um resultado mais conclusivo, sobre estrutura e interações sociais de Desmodus, no local de alimentação, em condiçōes naturais.

Os sons agudos e repetitivos, emitidos por um dos morcegos em fuga e a imediata reação de indivíduos próximos, sugerem a existência de um possível "grito de alarme", nesta espécie de morcego hematófago. Por se tratar de observação única, a interpretação dada deve ser encarada com reservas (grito de alarme em quirópteros é conhecidos no gênero Rhinolophus, Rhinolophidae, sendo emitido em frequência ultra-sônica, Gould, 1970).

\section{D) Localização e número de mordeduras no gado}

A localização das mordeduras e a ordem de preferência indicada pelos dados colhidos em Campinas concorda, parcialmente, com Ruschi (1951a) e Crespo et al. (1961) no caso dos equinos; para os bovinos, os meus dados concordam melhor com as informaçбes de Greenhall et al. (1971). Turner (1975) encontrou uma maior variação na localização das mordeduras, pelo corpo das vítimas, durante a estação das chuvas $e$ apresentou diversas possibilidades para explicar esta variação. A mais engenhosa (baseada na maior natalidade de Desmodus durante a época úmida) considera a aprendizagem dos melhores locais para a mordida, por parte dos morcegos jovens, como uma das possíveis causas da variação. Uma outra explicação, do mesmo autor, considera o fato do gado se dispersar mais, durante o descanso, na estação chuvosa. E, finalmente, há a considerar uma possível variação geográfica na preferência dos morcegos por um certo local no corpo das vítimas (Dalquest, 1955; Turner, 1975).

Acredito que uma variação na ordem de "preferência" dos morcegos, por um determinado local na vítima, possa também indicar uma certa diversidade no comportamento individual destas vítimas. Por exemplo, os animais que costumam deitar, frequentemente, estando a sua cabeça apoiada no chão, apresentam maior probabilidade de serem mordidos na região das narinas, que outros sem este costume (para morder dentro da narina, o morcego assume a postura quadrúpede, apoiado no chão, ao lado da cabeça da vítima). Nos equinos, a maior "preferência" pela região da cabeça poderia ser explicada pela maior facilidade de apreensão em crina (quando comparada ao pelo), que o morcego teria ao se alimentar neste tipo de gado. Em certas regióes do estado 
de São Paulo, há o costume de cortar a crina dos equinos e muares, para diminuir a incidência de mordeduras na região da cabeça e do pescoço (Marlies Sazima, comunicação pessoal; observações pessoais). Como já foi discutido, nestes casos talvez seja melhor não pensar em termos de "preferência" por um certo local no corpo da vítima e sim na sua "acessibilidade", atributo que pode variar com os hábitos das vítimas e as possíveis posturas e posições adotadas pelos morcegos, na ocasiâo. Por outro lado, certamente há uma preferência, no sentido mais restrito do termo, por certos locais mais apropriados à mordida, dependendo dos graus de espessura da pele, pilosidade da região e outros fatores, comentados por Greenhall (1972).

Thompson et al. (1972) e Mitchell \& Burns (1973), estudando Desmodus rotundus no México, consideraram o número de mordeduras encontradas no gado, como correspondentes ao número de morcegos visitantes, podendo, segundo estes autores, tal relação ser usada na estimativa da população de hematófagos numa certa localidade. Em Campinas, o número de mordeduras/vítima/noite não traduz o número de individuos que se alimentaram no gado, devido à existência da sucessão de diversos deles numa única mordedura, fato já comentado por Schmidt et al. (1970), no México. Turner (1975) sugeriu vantagem seletiva para esta sucessão, baseado nos dados de Greenhall (1972) sobre o tempo necessário para abrir uma ferida nova où usar uma já existente.

O maior número de mordeduras sofridas pelos equinos, em relação aos bovinos, pode indicar uma preferência de Desmodus por este primeiro tipo de gado, como fora mencionado por Crespo et al. (1961) e Turner (1975). Por outro lado, existe a possibilidade dos morcegos não usarem, nos equinos, uma mordedura já existente, como o fazem nos bovinos. Esta hipótese parece viável, considerando o fato dos equinos repousarem geralmente em pé e serem relativamente mais móveis que os bovinos. A isto pode ser somada a relativa dificuldade que um morcego poderia ter para alcançar, em postura pendurada, uma ferida já existente na cabeça ou no flanco da vítima. Neste caso, o maior número de mordeduras não estaria indicando a tendência de atacar mais um tipo de gado que outro. Dalquest (1955) comentou sobre a variabilidade da preferência por um certo tipo de gado, nas diversas localidades do México. Uma razoável idéia sobre a existência ou não da preferênçia por equinos ou bovinos, numa determinada região, somente poderá ser alcançada pela observação e contagem direta dos visitantes, ao invés da contagem de mordeduras sofridas pelo gado.

Os resultados obtidos em Campinas indicam, também uma preferência dos morcegos I por determinadas vítimas num grupo de animais, sem, entretanto, fornecerem evidência adicional sobre os fatores envolvidos, especulados por Greenhall (1965b), Villa-R. (1966), e Schmidt et al. (1970), entre outros, Não me parecem relacionados à cor da vítima, opinião que compartilho com Turner (1975), que submeteu esta hipótese a observações experimentais. Todavia, notei em diversas ocasiōes que equinos muito calmos tendiam a ser mais mordidos. Turner (1975) observou bezerros serem preferidos a adultos e relacionou esta preferência ao fato dos jovens repousarem por períodos mais longos, à noite, e portanto ficam mais expostos aos ataques dos morcegos. Além deste, os outros resultados obtidos pelo autor citado (preferência por gado Suíço sobre o Brahma e por fêmeas no estro sobre machos) foram relacionados à maior exposição espacial, no rebanho, das vítimas preferidas.

Ruschi (1951a) mencionou que, numa determinada vítima, uma ferida era rea- 
berta pelo mesmo morcego nas noites subsequentes e diversos autores observaram que a reabertura consecutiva de feridas é comum (Ditmars \& Greenhall, 1935; Greenhall, 1956b). Young (1971) afirmou que, nos poucos casos por ele observados, as vítimas nem sempre eram atacadas em noites subsequentes. As minhas observaçōes mostraram que apenas cerca de $10 \%$ do número total de mordeduras podia ser reaberto na noite seguinte. Entretanto, há a possibilidade deste comportamento variar regional, sazonal ou individualmente. As diversas possibilidades poderiam ser verificadas usando marcação dos morcegos, juntamente com cuidadoso mapeamento das mordeduras no corpo das vítimas, em observações ao longo do ano.

Em conclusão, este breve estudo confirmou que os problemas na observação dos hábitos de Desmodus rotundus são numerosos e, numa boa parte das vezes, de solução trabalhosa. Uma outra conclusão parece-me inevitável: não há conhecimento suficiente sobre o comportamento e a ecologia das populaçōes brasileiras desta espécie, para aplicação em eventuais programas de controle e erradicação.

\section{AGRADECIMENTOS}

Agradeço à família Van Schelle pelas facilidades de trabalho na Fazenda Atalaia, de sua propriedade e a Julie Dutilh pela indicação da colônia de Desmodus. A Wilson Uieda, João Semir e Augusto S. Abe e aos administradores Francisco e Florisvaldo, sou grato pelo auxilio nos trabalhos de campo. Aos Drs. Valdir A. Taddei, Adriano L. Peracchi, Deoclecio de Queiroz Guerra, Edwin O. Willis e Woodruff W. Benson, agradeço as sugestōes e leitura do manuscrito. E, finalmente, sou grato a Marlies, minha esposa, pelo auxílio e estímulo em todas as etapas do trabalho.

\section{REFERÊNCIAS BIBLIOGRĀFICAS}

ÁVILA-PIRES, F D. 1965. Biologia dos quirópteros e raiva dos herbívoros. II Simp. Bras. Raiva, Soc. Bras. Med. Veter., 80-88.

BROSSET, A. 1964. Utilisation de l'écholocation par les Chiroptères sur leur territoire nocturne. Mammalia, 28 (3): 323-338.

CARVALHO, C. T. 1969. Contribuição para a biologia dos morcegos hematófagos (Chiroptera, Desmodidae). Tese, Univ. S. Paulo, 84 p.

CONSTANTINE, D. G. 1970 . Bats in relation to the health, welfare and economy of man. p. 319-449. In W. A. WIMSATT (ed.), Biology of bats. 2. Academic Press, New York. 477 p.

CRESPO, J.A., J.M. VANELLA, B. D. BLOOD \& J.M. de CARLO. 1961. Observaciones ecológicas del vampiro Desmodus r. rotundus (Geoffroy) en al norte de Córdoba. Revta. Mus. Argent. Cienc. Nat. "Bernardino Rivadaviz", Inst. Nac. Invest. Cienc. Nat., 6 (4): 131-160.

CRESPO, R. F., S. B. LINHART, R. J. BURNS \& G. C. MITCHELL. 1972. Foraging behavior of the common vampire bat related to moonlight. J. Mamm., 53 (2): 366-368.

DALQUEST, W. W. 1955. Natural history of the vampire bats of eastern Mexico. Amer. Mid, Nat., $53(1): 79-87$.

DITMARS, R. L. \& A. M. GREENHALL. 1935. The vampire bat. Zoologica (New York), 19 (2): 53-76. 
EWER, R. F. 1968. Ethology of mamals Logos Press, London, xiv+ 418 p.

GILlETE, D. D. \& J. D. KIMBROUGH. 1970. Chiropteran mortality. p. 262-283. In B. H. SLAUGHTER \& D. W. WALTON (eds.), About bats Southern Methodist Univ. Press, Dallas, $339 \mathrm{p}$.

GLASS, B. P. 1970. Feeding mechanisms of bats. p. 84-92. In B. H. SLAUGHTER \& D. W. WALTON (eds.), About bats. Southern Methodist Univ. Press, Dallas, 339 p.

GOODWIN, G. G. \& A. M. GREENHALL. 1961. A review of the bats of Trinidad and Tobago. Bull. Amer. Mus. Nat. Hist., 122:187-301.

GOULD, E. 1970. Echolocation and communication in bats. p. 144-161. In B. H. SLAUGHTER \& D. W. WALTON (ed.), About bats. Southern Methodist Univ. Press, Dallas. 339 p.

GREENHALL, A. M. 1965a. Notes on behavior of captive vampire bats. Mammalia, 29(4): 441-451.

GREENHALL, A. M. 1965b. Aspects of ecology in vampire bat control in Trinidad. An. II Congr. Latino-Americano Zool., 2: 321-325.

GREENHALL, A. M. 1970. The use of a precipitin test to determine host preferences of the vampire bats, Desmodus rotundus and Diaemus youngi. Bijdr. Dierk., 40 (1): 36-39.

GREENHALL, A. M. 1972. The biting and feeding habits of the vampire bat, Desmodus rotundus J. Zool. (London), 168:451-461.

GREENHALL, A. M., U. SCHMIDT \& W. LOPEZ-FORMENT. 1971. Attacking behavior of the vampire bat, Desmodus rotundus, under field conditions in Mexico. Biotropica, 3 (2): 136-141.

HENSEL, R. 1869. Beitrage zur Kenntniss der Thierwelt Brasiliens (Fortsetzung). Der Zool. Garten, Frankfurt A. M., 10:135-140.

HUSSON, A. M. 1962. The bats of Suriname. Zool. Verh., Rijkmuseum Nat. Hist., Leiden, 58: 1-282.

LINHART, S. B., R. F. CRESPO \& G. C. MITCHELL. 1972. Control de murciélagos vampiros por medio de um anticoagulante. Bol. Ofic. Sanit. Panamer., 73 (2): 100-109.

MANN, G. 1950. Succión de sangre por Desmodus, Invest. Zool. Chilenas. 1: 7-8.

MANN, G. 1951. Biologia del vampiro. Biologica (Santiago). 12-13: 3-24.

MITCHELL, G. C. \& R. J. BURNS. 1973. Chemical control of.vampire bats. U. S. Bureau of Sport Fisheries and Wildlife.

MOOJEN, J. 1939. Sanguivorismo de Diphylla ecaudata Spix em Gallus gallus domesticus (L.). O Campo (Rio de Janeiro), 10 (114): 70.

RUSCHI, A. 1951a. Morcegos do Estado de Espírito Santo. Família Desmodontidae, chave analítica para os gêneros e espécies representados no E. E. Santo. Descrição de Desmodus rotundus rotundus e algumas observaçōes a seu respeito. Bolm. Mus. Biol. "Prof. Mello Leitễo", Zool., 2: 1-10.

RUSCHI, A. 1951b. Morcegos do Estado de Espírito Santo. Descriçao de Diphylla ecaudata Spix e algumas observaçōes a seu respeito. Bolm. Mus. Biol. "Prof. Mello Leitāo", Zool., 3: 1-9.

SCHMIDT, U. \& A. M. GREENHALL. 1972. Preliminary studies on the interactions between feeding vampire bats, Desmodus rotundus, under natural and laboratory conditions. Mammalia, 36 (2): $241-246$.

SCHMIDT, U., A. M. GREENHALL \& W. LOPEZ-FORMENT. 1970. Vampire bat control in Mexico. Bijdr. Dierk., 40 (1): 74-76.

TORRES, S. 1934. Morcegos da família "Desmodontidae" e seu papel na transmissão de molestias aos animaes. Revta. Dept. Nac. Prod. Animal, 1 (5-6): 25-35. 
THOMPSON, R. D., G. C. MITCHELL \& R. J. BURNS. 1972. Vampire bat control by systemic treatment of livestock with an anticoagulant. Science, 177:806-808.

TURNER, D. C. 1975. The vampire bat. A field study in behavior and ecology. Johns Hopkins Univ. Press, Baltimore, $x+145$ p.

VAUGHAN, T. A. 1972. Mammalogy. W. B. Saunders, Philadelphia, viii+463 p.

VILlA-R., B. 1966. Los muciélagos de México. Inst. Biol., Univ. Nal. Autón. México, 491 p.

VILLA-R., B. N. M. DA SILVA \& VILLA-CORNEJO. 1969. Estudio del contenido estomacal de los murciélagos hematófagos Desmodus rotundus rotundus (Geoffroy) y Diphylle ecaudata ecaudata Spix (Phyllostomatidae, Desmodinae). An. Inst. Biol. Univ. Nal. Auton. México, 40, ser. Zool. (2): 291-298.

WALKER, E. P. 1975. Mammals of the world. Johns Hopkins Univ. Press, Baltimore, 3. ed., 2 vol., $1500 \mathrm{p}$.

WIMSATT, W. A. 1969. Transient behavior, nocturnal activity patterns, and feeding efficiency of vampire bat (Desmodus rotundus) under natural conditions. J. Mamm., 50(2): 233-244.

YOUNG, A. M. 1971. Foraging of vampire bats (Desmodus rotundus) in Atlantic wet lowland Costa Rica. Revta. Biol. Trop., 18 (1,2): 73-88. 
